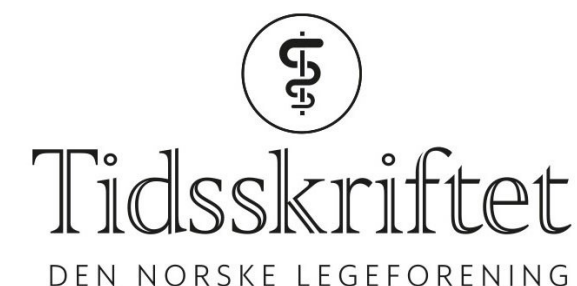

DEN NORSKE LEGEFORENING

\title{
En fin sommer
}

FRA REDAKTØREN

\section{ARE BREAN}

E-post:are.brean@tidsskriftet.no

Are Brean er sjefredaktør i Tidsskriftet. Han er spesialist i nevrologi og ph.d.

Klimaendringene er en av våre største helseutfordringer. Det siste vi trenger for å møte dem er egne fantasivirkeligheter og tøvete konspirasjonsteorier.

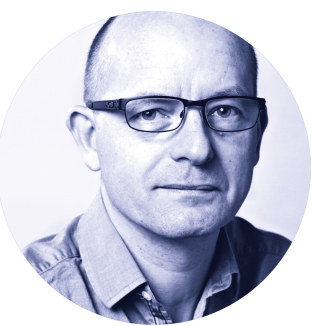

Foto: Einar Nilsen

"Jeg synes vi er heldige som har fått en så fin sommer i år», uttalte stortingsrepresentant for regjeringspartiet FrP Kari Kjønaas Kjos til Aftenposten 28. juli (1). Hun tror ikke på menneskeskapte klimaendringer og begrunner det blant annet med at det var mye regn i fjor sommer (1).

Sommeren i år har virkelig vært fin - for de fleste av oss. Men noe skurrer. Ganske mye, egentlig. For sommeren har ikke vært like fin for alle. Den tørreste sommeren på 117 år har gitt en dramatisk reduksjon av landets kornavlinger, helt ned mot $40 \%$ av normalen, mens melkebønder må sende dyrene til slakt fordi de er usikre på om de klarer å skaffe nok fôr (2). Dersom en slik sommer i Norge inntreffer som følge av tilfeldige variasjoner, vil det skje sjeldnere enn én gang per 10 ooo år (3). Løfter vi blikket enda litt høyere opp fra navlen og ser helt til Sverige, ser vi det verste utbruddet av skogbranner som noen gang er registrert der, med over 50 skogbranner i midten av juli (4).

Også resten av kloden har hatt ekstremvær: Mer enn go mennesker er døde etter skogbranner i Hellas, og i California pågår den største brannen i moderne historie der $(5,6)$. Hittil i 2018 i USA er det registrert seks værkatastrofer som hver har ødelagt verdier for over 1 milliard dollar, og med minst 36 dødsfall (4). I Japan har rekordregn i juni ført til ekstrem flom og over 200 dødsfall, før ekstremvarme i juli ga ytterligere dødsfall og 22000 sykehusinnleggelser på grunn av heteslag $(4,5,7)$. Ikke alle har vært like heldige med sommeren som stortingsrepresentant Kjos.

Det er særdeles godt vitenskapelig dokumentert at klimaet over hele kloden er i rask endring som følge av global oppvarming. Det er også særdeles godt vitenskapelig dokumentert at oppvarmingen er menneskeskapt og skyldes utslipp av drivhusgasser $(4,5$, 
7-9). Helsekonsekvensene er allerede tydelige, og vil bli verre: Selv med en drastisk reduksjon av utslipp av drivhusgasser, vil 48 \% av klodens innbyggere i år 2100 oppleve minst 20 årlige dager med dødelige hetebølger (definert som en kombinasjon av varme og fuktighet som overstiger kroppens evne til å kvitte seg med overskuddsvarme)(10). Dersom dagens utslippsrate opprettholdes, vil det samme gjelde hele $74 \%$ av klodens innbyggere. 250 ooo menneskeliv vil gå tapt årlig mellom år 2030 og 2050 som konsekvens av klimaendringene (9). Svekket matsikkerhet og matkvalitet som følge av økt $\mathrm{CO}_{2}$-innhold i atmosfæren vil gi store globale helsekonsekvenser. Men nær halvparten av dette kan teoretisk sett unngås ved et betydelig kutt i globale utslipp (11).

Klimaendringene er her allerede (9). Selv om mange av de dystre konsekvensene fortsatt kan unngås, må vi uansett belage oss på mer ekstremvarme og -nedbør i årene som kommer, også i Norge. For å minimere helsekonsekvensene trengs det nasjonale beredskapsplaner for stadig mer ekstremt og uforutsigbart vær. Kampen mot oppvarmingen er global, men forebygging av helsekonsekvensene er i stor grad nasjonal og lokal. Vitenskapen gir faktaene og prognosene. Tiltakene er et politisk ansvar.

Da er det forstemmende at Kjos ikke er den eneste nasjonale politikeren som lar observasjoner fra stuevinduet være bestemmende for hvorvidt hun har tillit til vitenskapelig dokumentasjon. Hennes stortingskollega Jon Helgheim bortforklarer vitenskapelige fakta med konspirasjonsteorier om at verdens klimaforskere «følger pengene» i jakten på svarene som oppdragsgiverne (regjeringen?) gjerne vil ha (12). De minner begge sterkt om den amerikanske kongressmannen Mo Brooks, som har en teori om at de siste årenes økning av havnivået ikke skyldes klimaendringer, men at det faller biter av Dovers hvite klipper ned i havet (13).

Klimaendringene er blant vår tids største globale helseutfordringer. De truer forbedringene som er oppnådd i global helse de siste tiårene (9). Mer enn noen gang trenger vi politikere som stoler på vitenskapelig dokumentasjon og ikke holder seg med egne fantasivirkeligheter og tøvete konspirasjonsteorier.

\section{LITTERATUR:}

1. Mauren A, Riaz WK. SV: Regjeringen er handlingslammet i klimaarbeidet - FrP: Vi er heldige som har hatt en fin sommer. Aftenposten 28.7.2018.

https://www.aftenposten.no/norge/politikk/i/1kp6yB/SV-Regjeringen-er-handlingslammet-i-klimaarbe idet-Frp-Vi-er-heldige-som-har-hatt-en-fin-sommer (9.8.2018).

2. NTB. Tørken gir dårligste kornavlinger på over 50 år. Adresseavisen 31.7.2018.

https://www.adressa.no/nyheter/innenriks/2018/o7/31/T\%C3\%B8rken-gir-d\%C3\%A5rligste-kornavlinger-p \% 3 \%

3. Bjerkan L. Disse grafene viser hvor ekstrem Oslo-sommeren har vært. Aftenposten 1.8.2018.

https://www.aftenposten.no/osloby/i/LoO3Q1/Disse-grafene-viser-hvor-ekstrem-Oslo-sommeren-har-va $\mathrm{rt}(9.8 .2018)$.

4. World Meteorological Organization. July sees extreme weather with high impacts. https://public.wmo.int/en/media/news/july-sees-extreme-weather-high-impacts (8.8.2018).

5. NTB. Professor:- Alvorlige klimaendringer utspiller seg foran øynene våre. Dagens Næringsliv 2.8.2018.

https://www.dn.no/nyheter/2018/o8/o2/o6o4/Klima/professor-alvorlige-klimaendringer-utspiller-seg-f oran-oynene-vare (9.8.2018).

6. Tchekmedyian A, Qeally J, Serna J. Mendocino fire becomes biggest in modern California history as weary firefighters brace for more. Los Angeles Times 7.7.2018.

http://www.latimes.com/local/lanow/la-me-fires-mendocino-2018o8o7-story.html (8.8.2018).

7. Heatwaves and health. Lancet 2018; 392:359. [CrossRef]

8. Intergovermental Panel on Climate Change (IPCC). Climate change 2014. Synthesis report. http://www.ipcc.ch/pdf/assessment-report/ar5/syr/SYR_AR5_FINAL_full_wcover.pdf(8.8.2018). 
9. World Health Organisation. Climate change and health.

http://www.who.int/en/news-room/fact-sheets/detail/climate-change-and-health (8.8.2018).

10. Mora C, Dousset B, Caldwell IR et al. Global risk of deadly heat. Nat Clim Chang 2017; 7: 501 - 6. [CrossRef]

11. Ebi KL, Ziska LH. Increases in atmospheric carbon dioxide: Anticipated negative effects on food quality. PLoS Med 2018; 15: e10026oo. [PubMed][CrossRef]

12. Koker kloden på konspirasjonsteorier. Dagbladet 10.7.2018.

https://www.dagbladet.no/kultur/koker-kloden-pa-konspirasjonsteorier/70oo1596 (8.8.2018).

13. Jacobs B. Republican congressman explains sea-level rise: it's rocks falling into the sea. The Guardian 17.5.2018.

https://www.theguardian.com/environment/2018/may/17/republican-congressman-mo-brooks-sea-lev el-rise-rocks (8.8.2018).

Publisert: 21. august 2018. Tidsskr Nor Legeforen. DOI: 10.4045/tidsskr.18.0621

(C) Tidsskrift for Den norske legeforening 2020. Lastet ned fra tidsskriftet.no 